\title{
Partners edge closer to vital step on fusion
}

Quirin Schiermeier, Munich

Fusion research received a tentative boost last week when the member states of the European Union (EU) reaffirmed their commitment to build the International Thermonuclear Experimental Reactor (ITER), the experiment regarded as a vital next step towards realizing fusion energy.

Last week, the European Council of Research Ministers gave an official mandate to the European Commission to start negotiations with Russia and Japan over the details of ITER's construction and operation. The negotiations will cover the legalities of ITER operation, the structure of its management, recruitment of staff, their terms of employment and the search for an appropriate site for the reactor.

But the research ministers also asked the commission for a full report on the current state and likely future direction of fusion research, to help them decide whether to proceed with ITER's construction.

The commission must also specify the likely cost of the project, its environmental impact, the timetable for its completion and its place in the EU's Framework research programme.

The design and cost of ITER have changed significantly since the project was first conceived. Under its initial configuration, it would have cost 6.7 billion euros (US\$5.8 billion) and achieved ignition -

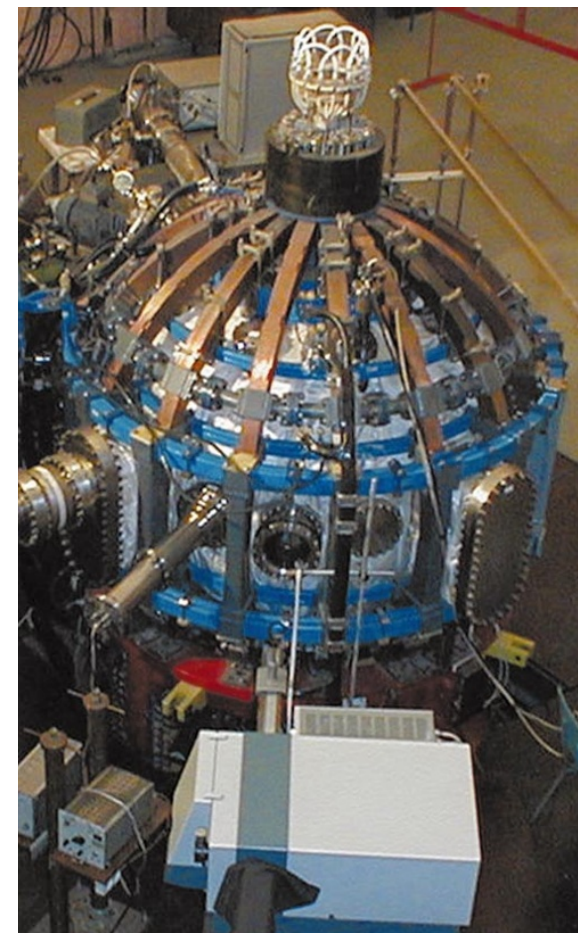

Fired up: the international project would build a larger version of this Russian Tokamak reactor.

the point at which fusion becomes selfsustaining.

But after the withdrawal of the United States from the project, which took effect in 1999, it was trimmed down to a version known as ITER-FEAT (for Fusion Energy Advanced Tokamak). This machine will not attain ignition and will cost an estimated 3.6 billion euros.

Annual European fusion research costs are around 500 million euros, $40 \%$ of which come from the EU's research budget, with the rest coming from the member states. The EU share of construction costs for ITER-FEAT must be earmarked in the next Framework programme of research, which starts in 2003.

Fusion scientists hope that the decision will keep Europe on course for participating in ITER's construction. 'Last week's agreements are an important step for the European fusion programme, and will take fusion research forward," says Alexander Bradshaw, scientific director of the Max Planck Institute for Plasma Physics in Garching, near Munich, the main base of the European ITER project team.

Despite continuing uncertainty about whether fusion energy is feasible, all EU member states have approved the agreement. But some still have doubts.

For example, Wolf-Michael Catenhusen, the German secretary for research, admits that it was premature for the council to give the go-ahead to negotiate details of the project before the member states had come to a decision about the value of fusion energy in principle.

http://www.iter.org

\section{French target research money at allaying BSE fears}

\section{Declan Butler, Paris}

The French government has announced plans to triple the funding of research on prions, which are thought to cause bovine spongiform encephalopathy (BSE) in cattle, from 2001.

Prime Minister Lionel Jospin announced the increase, from FFr70 million to FFr210 million (US\$27 million), as part of his government's seven-point plan for dealing with mounting public concern in France about BSE.

The extra money is for research on prion-related diseases, tests to detect the diseases in animals, methods of destroying meat and bone-meal, epidemiological research and the development of therapeutic methods for controlling variant Creutzfeldt-Jakob disease (vCJD), the human form of the disease. The use of meat and bone-meal in animal feed is also being suspended.

The plan will create several new laboratories, and jobs for 120 researchers and technicians. The many agencies involved in BSE research in France are also to be more closely coordinated.

In the week before Jospin's statement, President Jacques Chirac had made a public statement demanding the immediate banning of meat and bone-meal in animal feed and the systematic testing of all French cattle for BSE. Jospin had preferred to wait for recommendations from government food-safety experts, expected in three or four months, but Chirac's statement forced his hand.

Jospin, quoting the French food safety agency, said at a press conference that there was "no scientific evidence to show that eating meat and milk from cattle represents a health risk".

The French BSE crisis, with 183 cases in cattle and three cases of vCJD, is smaller than that in the United Kingdom. But with the contaminated blood scandal, in which three former government ministers were taken to court for involuntary homicide (see

๑ 2000 Macmillan Magazines Ltd

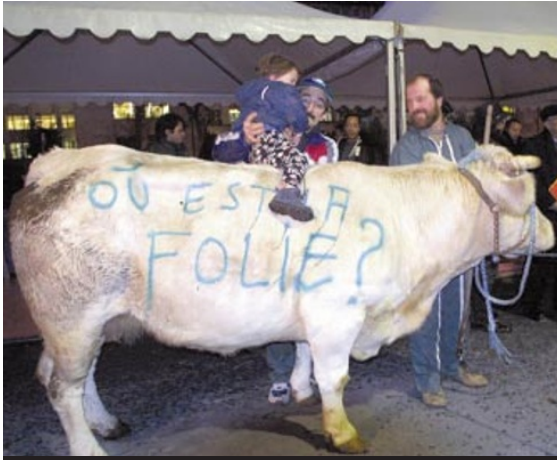

La vache folle: a French protest against BSE.

Nature 397, 548; 1999), fresh in the public mind and following the Phillips report on the British BSE crisis, both Chirac and Jospin felt obliged to act.

Two of the families of French victims of vCJD are filing lawsuits against "persons unknown" for poisoning and involuntary manslaughter, targeting British, French and European authorities. 